\title{
8
}

\section{A RANGE OF INVESTMENTS}

In reviewing the Commonwealth Mining Investments (Australia) (CMI) portfolio, Gerald Mortimer became interested in mineral sands and, in particular, rutile and zircon mining activities being undertaken along the beaches of New South Wales and Queensland. His interest was drawn to an investment in Wyong Minerals that was undertaking dredging operations near Lake Munmorah in New South Wales. CMI had a shareholding in Wyong Minerals and had advanced loans to the value of $A £ 170,000$ on the surety of shares in the company. The shares were trading below their par value. According to Ted Wiles, who assisted Mortimer with his analysis of investment opportunities in Australia:

With [Wyong two shillings and sixpence] shares selling at 9d [ninepence] and rutile/zircon in the doldrums it did not look very hopeful but piqued Gerry's interest and was the germ of the subsequent much larger move into the mineral sands industry as demand for the commodity improved. ${ }^{1}$

CMI also sponsored the listing of Western Titanium, which had acquired mineral sands tenements in the south-west of Western Australia and established mineral sands mining, concentrating and processing operations near the rural township of Capel. CMI had also established an investment in Associated Minerals Consolidated (AMC) in 1957. Within its portfolio in 1960, mineral sands represented 9 per cent of all investments: 11 per cent in 1964 and 19 per cent by 1966 .

1 Ted Wiles, personal communication, 17 January 2018. 
In March 1962, Consolidated Gold Fields (Australia) (CGFA) through its own investments and that of CMI had secured a 75 per cent indirect interest in Wyong Minerals. In 1963, the Wyong Minerals' loans were converted to shares and the placement was allocated to CGFA. In that year, CGFA took over the role as general manager of Wyong Minerals. Through CMI and its own direct investments, Gold Fields could see clear advantages in taking a controlling position in the Australian mineral sands sector. It had the ability to acquire a position in the established east-coast industry, as well as to gain a foothold in the emerging industry in Western Australia. Demand for rutile for the manufacture of titanium metal as well as its direct use for welding rod coatings was viewed as favourable. EI du Pont de Nemours and other United States' pigment manufacturers were seeking supplies of chloride feedstocks for the new chloride process of titanium dioxide pigment manufacture. These feedstocks included both rutile and weathered ilmenites, essential for the emerging chloride pigment process that was replacing the traditional reliance on lead-based pigments in paint. Mortimer advised his Londonbased directors that consolidation and efficiencies in the industry would aid Australia's market position as an international supplier, as well as the business position of CGFA. This prognosis played out as CGFA established itself as the major global producer in mineral sands.

Mortimer's interest in mineral sands reinforced the favourable impression that George Harvie-Watt had of the industry during his visits to Australia. In 1961, after a review of the mineral sands industry and its participants, a majority shareholding was established in AMC. In a letter to the AMC managing director and founder, Joseph Pinter, Frank Beggs wrote that CGFA wished Pinter to remain as managing director, stating: 'It is the policy of Gold Fields to leave management in the hands of the individual Boards of subsidiaries, and I confirm that it would be our intention to follow the policy in the case of Associated'. ${ }^{2}$

Pinter, an enterprising Hungarian émigré, travelled to Australia with his wife Gerda, arriving in Melbourne in May $1935 .{ }^{3}$ Pinter had an association with a company from which he obtained a licence to manufacture welding machines and welding rods in Australia. He established a workshop, initially in North Melbourne and later in Carlton. After the fall of France during World War II, Pinter's British supplier could no longer supply

2 Letter from Frank Beggs to J Pinter, 6 September 1961, Renison Goldfields Consolidated Archives (RGCA), Box 40938.

3 Based on notes related to Joseph Pinter prepared by IW Morley, author of Black Sands: A History of the Mineral Sand Mining Industry in Eastern Australia. See also Routh, 'Pinter, Joseph (1912-1981)'; Associated Minerals Consolidated Limited, 'Annual Report and Notice of Meeting 1977', pp. 8-9; and interview of Pinter in The Australian, 6 December 1969. 
rutile for welding rods. Instead, Pinter was advised that the material was available from the beach sands on the coast of northern New South Wales. He obtained concentrate from a company operating at Byron Bay. Given this was a mixed concentrate, containing rutile and ilmenite, a means had to be found to separate the rutile. Pinter determined that separation could occur by electromagnetic methods and developed his own separation equipment. A separator was designed and built with whatever materials he could obtain during the constraints of wartime Australia. Through Pinter's separation process, ilmenite, the dominant magnetic fraction, was removed from the concentrate. The concentrate also contained zircon. Pinter designed an electrostatic separator to separate the zircon from rutile.

Quantities of rutile, the highest-grade titanium material, became available for the first time in Australia. The product was shipped to England under special wartime arrangements. Southport, Queensland, where the concentrate was sourced, became the centre of Pinter's operations. Pinter came to an arrangement with a newly formed company, Southport Minerals, and another group, British Minerals, to form Associated Minerals, in which Pinter held a 50 per cent interest. The company acquired titles to mineral deposits near Broadbeach and around Southport as well as on Moreton Island. Pinter upgraded the processing facilities at Southport, installing his own designed electrostatic and electromagnetic separators. The company was publicly listed in 1953 as Associated Minerals Consolidated. Pinter, as managing director, remained in this position as the company evolved under the ownership of CGFA until he retired in 1977.

AMC's activities involved pegging tenements along the coastline of New South Wales, purchasing leases from other operators and acquiring operating companies. Rutile was initially mainly used for welding rod coatings and, to a lesser extent, for the production of titanium metal. Zircon mainly had foundry and refractory applications. AMC's early years were buoyant. Production and sales grew rapidly and with them profitability. While increased rutile output and lower demand caused a decline in the price of rutile, with some merchants and producers forced to sell at 'distressed prices', and failing to survive, it had little impact on the upward trajectory for AMC. According to its chairman, WE Hopkins, 1957 was 'most important in the development of our activities in the Southport-Cudgen area. ${ }^{4}$ By 1959 , AMC's rutile sales constituted 19 per cent of Australia's rutile sales, while the company was responsible for 22 per cent of the country's zircon sales.

4 Associated Minerals Consolidated Limited, 'Directors' Report to be Presented at the Fifth Annual General Meeting, to be held Tuesday, 17th December 1957', University of Melbourne Archives (UMA), JB Were and Son, 2000.0017, Unit 611. 


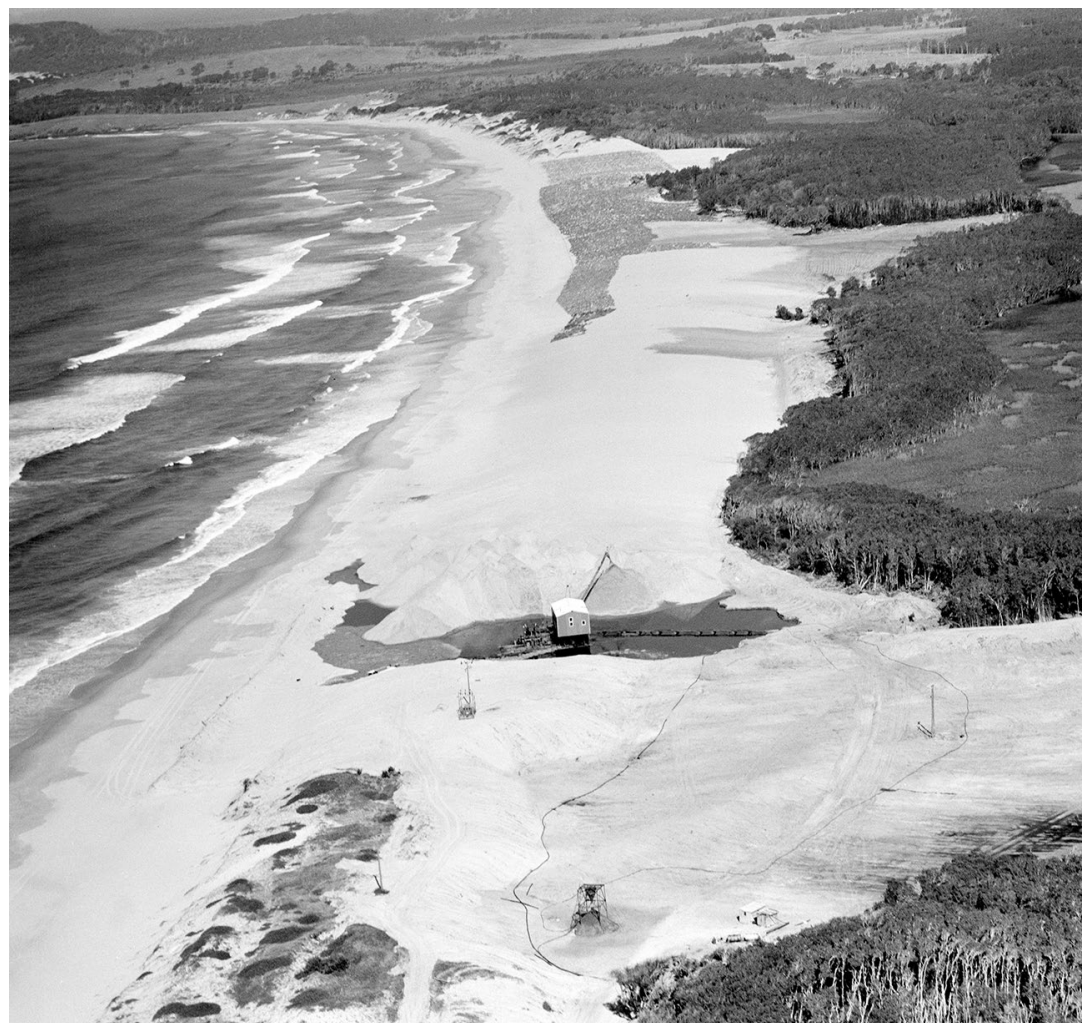

Figure 27. Beach dredge mining conducted by Associated Minerals Consolidated along the New South Wales coast.

Source: NAA, A1200, 191695.

In 1961 CGFA made a bid for 50 per cent of AMC's shares. The offer, supported by the board of AMC, enabled CGFA to acquire a 58 per cent interest in the company. With its new shareholder's support, AMC moved to acquire a number of other east-coast mineral sands producers. As the 1966 prospectus for the listing of CGFA stated, the company in this manner, contributed to the stabilization of what had been a depressed industry, and in the process, built itself into the largest producer of zircon and rutile in the world'. ${ }^{5}$ In 1962 CGFA made an offer for 50 per cent of the shares in Wyong Minerals other than those held by CMI. Wyong Minerals became its subsidiary. This and the AMC acquisition were well timed; the rutile price increased by 50 per cent during 1962, associated with chloride pigment producers seeking greater quantities of this material.

5 Consolidated Gold Fields Australia Limited, 'Prospectus', 18 October 1966, p. 3, UMA, 1974.0092, Box 857. 


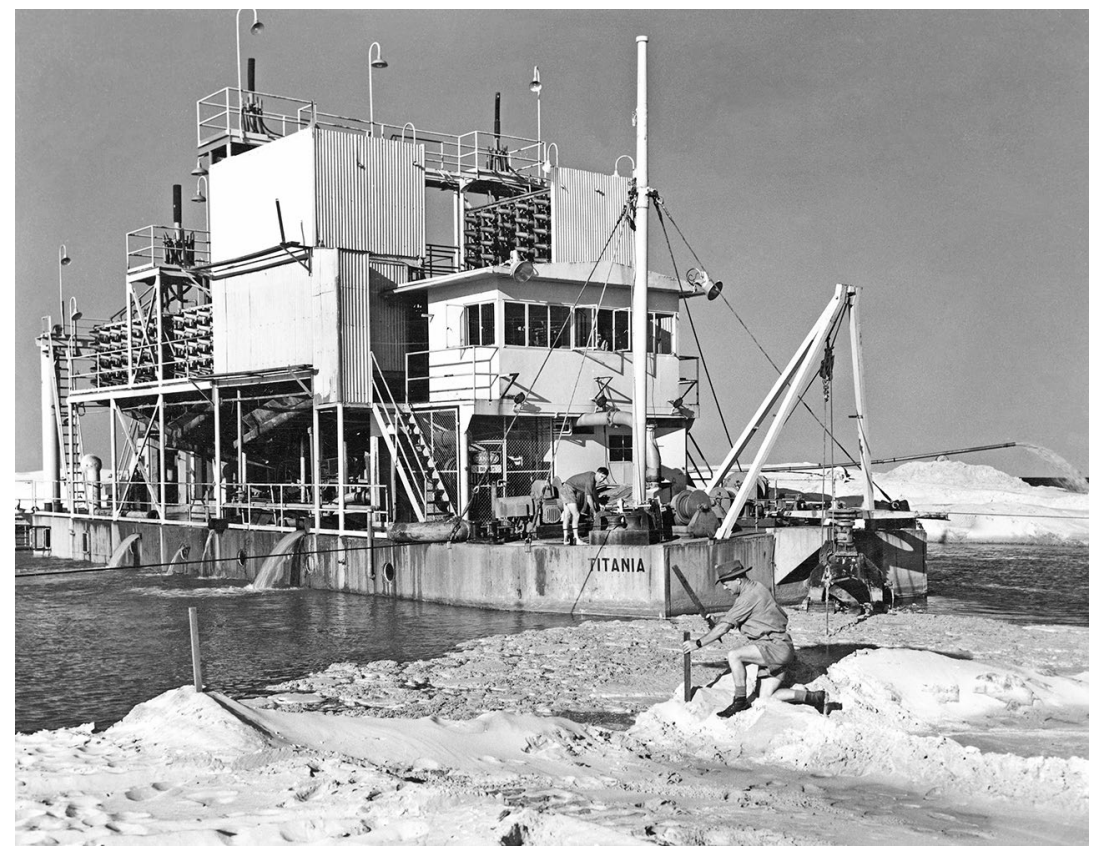

Figure 28. Titania dredge used on North Stradbroke Island, Queensland.

Source: NAA Mineral Sands Mining/5.

In the early 1960s, Australia produced 90 per cent of the world's rutile and approximately 60 per cent of its zircon. In terms of the overall minerals sector in Australia, rutile and zircon exports generated approximately A£11 million, relative to total mineral exports, including pig iron and gold of $A £ 109$ million and over $A £ 130$ million if thermal coal and coking coal were included. As such, while a relatively small sector, CGFA felt confident it had established a position of market influence, as well as further diversifying its minerals investment base. 


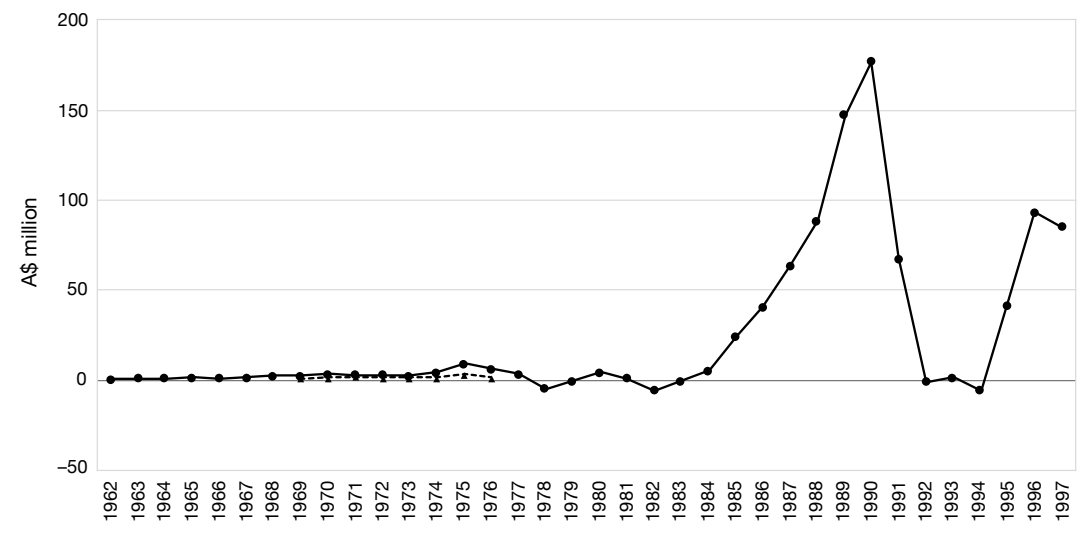

\section{Chart 1. Associated Minerals Consolidated pre-tax earnings, 1962-1997.}

Sources: Consolidated Gold Fields Australia Limited, 'Prospectus', 18 October 1966; CGFA and RGC annual reports, 1967 to 1997.

This chart shows the financial performance of CGFA's investment in AMC and subsequent division, AMC Minerals Sands. The years 1969 to 1976 include the contribution from an investment in Western Australian mineral sands producer, Western Titanium. AMC and Western Titanium merged in 1976. The chart reflects the low but relatively stable financial performance until the mid-1980s, when demand for chloride feedstocks, including rutile and synthetic rutile, as well as the demand for zircon, saw a marked appreciation in the financial contribution of mineral sands. In the context of a declining contribution from Renison and the challenges of Mount Lyell, CGFA and RGC developed a preponderant reliance on mineral sands, not reduced until the commencement of production from the Porgera gold operation in the early 1990s.

The initial investments in both CMI and AMC were successful for CGFA, with their combined profits up more than 40 per cent in the 1964 financial year to a new record of $A £ 600,000 .{ }^{6}$ Mineral sands became the major part of the portfolio, expanded by the later acquisition of Western Titanium and its merger with AMC. There followed an expansive program of exploration both in Australia and overseas, acquisition of other companies and technological developments, most notably the development of a technology for the beneficiation of ilmenite to a highergrade titanium dioxide product, to be referred to as synthetic rutile. ${ }^{7}$ Mineral sands remained the core part of the portfolio and differentiated the company from its other diversified peers; it would ultimately be a key factor in the aggregation of the successor company-Renison Goldfields Consolidated (RGC) — with another, smaller mineral sands company in the late 1990s.

6 The Times, 2 December 1964.

7 Typically, a 54 per cent titanium dioxide ilmenite was upgraded to a synthetic rutile product containing around 90 per cent titanium dioxide. 


\section{Iron ore- - the founding of a new industry}

Through New Consolidated Gold Fields (Australasia), exploration prospects for a range of minerals had been evaluated. These included a consideration of bauxite deposits at Gove Peninsula in eastern Arnhem Land, the potential development of an iron ore deposit at Frances Creek, both in the Northern Territory, and a joint venture with Utah Construction \& Mining for coal deposits in the Bowen Basin, Queensland. Wider geographical opportunities were also considered with a Consolidated Gold Fields London representative reviewing the Ok Tedi gold and copper mineralisation in Papua New Guinea. Gove and Ok Tedi were discarded as too large as financial undertakings and while drilling occurred at Frances Creek, the resource size was not considered sufficient to commit to further evaluation. ${ }^{8}$

The work of prospectors, notably Lang Hancock and Peter Wright, had identified extensive high-grade iron ore deposits in the Pilbara region of Western Australia, while the Western Australian Bureau of Mines, through its studies at Mount Goldsworthy, provided access to geological information of the potential of this area. New Consolidated Gold Fields (Australasia) conducted a joint exploration program with Cyprus Mines Corporation, a United States' company based in Los Angeles, which included an investigation of iron ore tenements in the Pilbara. Mortimer identified iron ore as one of the main mineral investment opportunities for the newly established Australian company.

Prior to 1960, opportunities to develop this mineral were impeded by the Commonwealth Government's restrictions on the export of iron ore, imposed in 1938. In December 1960, the embargo on iron ore exports was relaxed. This provided the impetus for CGFA to establish a presence in Australia's iron ore sector and with it make a contribution to the establishment of infrastructure that formed a basis of a major industry. It did so in the context of activities by Conzinc Rio Tinto's recently formed Australian subsidiary, Conzinc Riotinto Australia (CRA), in establishing its own major iron ore presence, as well as efforts by other companies near Robe River, Western Australia.

8 Ted Wiles, personal communication, 17 January 2018. 
In 1961, the Western Australian Government called for tenders to develop iron ore areas of Western Australia, including at Mount Goldsworthy. According to a Consolidated Gold Fields executive:

We were attracted by this proposition, but the size of the probable capital investment and our own inexperience in this field of open cast mining and bulk transportation of iron ore led us to decide to work in partnership with Cyprus Mines Corporation of Los Angeles and Utah Construction \& Mining Co. of San Francisco. ${ }^{9}$

CGFA joined with Cyprus and Utah to spread the risk and capital associated with a large and complex venture. Cyprus and Utah had a joint involvement in a Peruvian iron ore operation and through it established a marketing arm, Marcona, in which they held a combined majority interest. Marcona would be used for the initial marketing of iron ore from Mount Goldsworthy. ${ }^{10}$ Utah also brought a mining and construction capability, which proved crucial for the mine and infrastructure development. This included deepening of the entrance channel to Port Hedland, the harbour selected for the shipment of iron ore.

The Western Australian Government tender for the development of Mount Goldsworthy called for proposals for the production and export of up to 15 million tons of iron ore, out of an estimated 30 million tons of reserves. The restriction reflected the requirement to preserve half of the high-quality deposits for potential domestic Australian use.

9 DES Barton, 'The Mount Goldsworthy Project', in Consolidated Gold Fields Limited, 'Speeches Given at the Group Conference Held at Gleneagles Hotel, Scotland on 2-9 July, 1964', p. 165.

10 Marcona was owned 46.75 per cent by Cyprus and 42.25 per cent by Utah. The remaining equity interest was held by the founder and chief executive of this entity, Charles W Robinson. I am grateful to Dr David Moore for his input to this section. Moore was recruited by Bart Ryan in London as administration manager for Goldsworthy Mining Limited, where he worked from 1970 to mid-1976. Moore advised the author that the establishment of a dual corporate structure of Mount Goldsworthy Mining Associates and Mount Goldsworthy Pty Ltd was influenced by a requirement of the US participants to avail themselves of a depletion allowance available under the US taxation system, which required them to hold title to the ore. The taxation deductions available in Australia for expenditure to build infrastructure, such as townships for example, could be obtained only by the employing entity. To address this, Goldsworthy Mining was contracted at a fee, initially 10 per cent of cash operating costs (later reduced to 5 per cent), to manage the assets of the employing entity. Goldsworthy Mining was able to secure debt finance in Australia and enter into various non-mining leases, including that for the seabed for Port Hedland Harbour (David Moore, personal communication, 27 August 2018 and 6 September 2018). RIJ Agnew, grandson of John Agnew and later chief executive and chairman of Consolidated Gold Fields Limited, was seconded to Goldsworthy Mining as an administrative superintendent during the construction period for the Mount Goldsworthy project (RIJ Agnew, 'Mount Goldsworthy Iron Ore', Mining Magazine, December 1966, vol. 115, no. 6). 
The tender required the construction of a loading berth and ancillary harbour facilities at a port to be selected and provision of transport facilities by road or rail between the site and the harbour. If transportation was by rail, it needed to be capable of transporting 1 million tons per annum, with all rolling stock and other infrastructure supplied. Township facilities were also required to be built at Goldsworthy and at Finucane Island, opposite Port Hedland, the site of the port-loading facilities. Each tenderer was required to submit the level of royalty per ton they were prepared to pay. In January 1962, a joint venture, Mount Goldsworthy Mining Associates (MGMA) was established.

Six companies tendered for the right to develop the Mount Goldsworthy deposits; the MGMA joint venture was successful in winning the tender. In February 1962, an agreement was signed with the Western Australian Government for the development of 15 million tons of iron ore at an estimated capital expenditure of $A £ 12$ million and a commitment to pay a royalty on lump ore at the rate of 7.5 per cent. ${ }^{11}$ Three potential port locations were considered: Cape Keraudren, Port Hedland and Depuch Island. With the initial possibility that exports could be limited to 1 million tons, Port Hedland was ruled out due to the extent of dredging required, with preliminary studies suggesting that Depuch Island may be suitable for the port site. This site, located south of Port Hedland and 110 kilometres from the mining site, was also initially favoured by the Western Australian Government.

In June 1963 the Commonwealth Government liberalised export conditions for iron ore, removing completely the export embargo. That month an export licence was granted covering 64 million tons at a rate of 4 million tons per annum. ${ }^{12}$ The higher rate of production improved the economics of the project, but entailed a considerably larger level of capital expenditure, to over A£20 million. With the larger level of export tonnage granted, Port Hedland came back into contention as the most appropriate port on a cost and engineering basis.

11 The revenue was net of free-on-board for lump iron ore and 3.75 per cent for fines.

12 Mount Goldsworthy Mining Associates, 'Technical Proposals for the Development of the Mount Goldsworthy Iron Ore Deposits and Port Hedland Harbour’, February 1964, p. 1. 
The joint venture had three-and-a-half years to complete its evaluation and construction activities, with the final award of a mining licence dependent upon securing suitable sales contracts. In 1963, the feasibility study was underway, with engineers and geologists engaged in drilling and underground tunnelling. CGFA played a key role in feasibility study planning and also in geological and metallurgical evaluation of the deposits, while engineering work was conducted by Utah. The exploration program involved surface geological mapping, surface sampling, diamond drilling, construction of adits and vertical percussion drilling. The evaluation by MGMA determined 'large reserves of high quality iron ore' as well as supplementary deposits that could be developed. ${ }^{13}$ The drilling identified approximately 52 million tons of ore from the two initial ore bodies expected to be developed, although ore reserves of at least 190 million tons were identified on the tenements retained by the joint venture. ${ }^{14}$

In 1964 The Iron Ore (Mount Goldsworthy) Agreement Act was proclaimed authorising mining activity. The companies were also able to secure access to additional lease areas. Whereas the original agreement covered an area of 25 square kilometres, the new agreement provided an additional 19 'reserves' near to and west of Mount Goldsworthy, known as Area B, encompassing 400 square kilometres and another area, known as Area C, of 1,000 square kilometres to the south. ${ }^{15}$ According to one writer, the level of detailed evaluation undertaken of the joint venture 'emboldened them to seek to export the whole of the $64,000,000$ tons of the deposit at a rate of 4,000,000 tons per annum' rather than the initial tender for up to 15 million tons. ${ }^{16}$ The joint venture developed the Mount Goldsworthy deposit, known as Area A, and then moved to additional deposits at Shay Gap, Kennedy Gap and Sunrise Hill. Production began at 1.5 million tons and planned to exceed 10 million tons per annum. The leases for Mining Areas A, B and C were granted on 5 October 1964 and development commenced.

13 The Times, 14 December 1962.

14 DES Barton, 'The Mount Goldsworthy Project', in Consolidated Gold Fields Limited, 'Speeches Given at the Group Conference Held at Gleneagles Hotel, Scotland on 2-9 July, 1964', p. 167.

15 The Times, 16 October 1964.

16 Lee, Iron Country: Unlocking the Pilbara, pp. 33-34. 
Port facilities were built on Finucane Island, adjacent to Port Hedland, and an extensive dredging program was conducted by Utah over 26 months, deepening a 7-kilometre channel and creating a turning circle for vessels of up to 60,000 tons capacity. The construction contract for other infrastructure, which included diesel power generation at the mine and port, as well as facilities for crushing, railway, ship loading, water supply and telecommunications, and all buildings for employees and the plant and workshops, was executed in June 1965. ${ }^{17}$ A 110-kilometre railway line was constructed from Finucane Island to Goldsworthy. At Goldsworthy, a location without any existing infrastructure, a township had to be created in the barren red soil, with housing, recreational and sport facilities established and sewerage, water and power services for what became a population of over 800 people. Likewise, housing facilities were required on Finucane Island, with more than 60 houses constructed, as well as an apartment block for single employees. A causeway was built to connect Finucane Island to the mainland while the island became the site for ore crushing, stockpiling of ore and loading onto ships. In February 1965 MGMA, through its marketing arm, CIA San Juan SA, a subsidiary of Marcona, signed contracts with Japanese steel mills for the export of 16.5 million tons, beginning with the export of 1.5 million tons of ore in 1966 and then 2.5 million tons in each of the years from 1967 to $1972 .{ }^{18}$ The price struck for the first 2.75 million tons was at a rate higher than the subsequent volume contracted, with no escalation allowable in prices for cost increases over the duration of the contract. ${ }^{19}$

17 Material Contract No. 5 and Material Contract No. 6, in Mount Lyell Mining and Railway, Co, Consolidated Goldfields 1964-1966 Contracts, UMA, 1974.0067.

18 CIA San Juan marketed and shipped iron ore for its parent company, Marcona Mining Company (Peru). The initial contracts were for 100 millimetre $\times 6$ millimetre ore, considered to be an unusual product, which could include 20 per cent fines. This was later replaced by 30 millimetre $\times 6$ millimetre ore and fines (David Moore, personal communication, 6 September 2018).

19 Raggatt, Mountains of Ore, p. 121. 


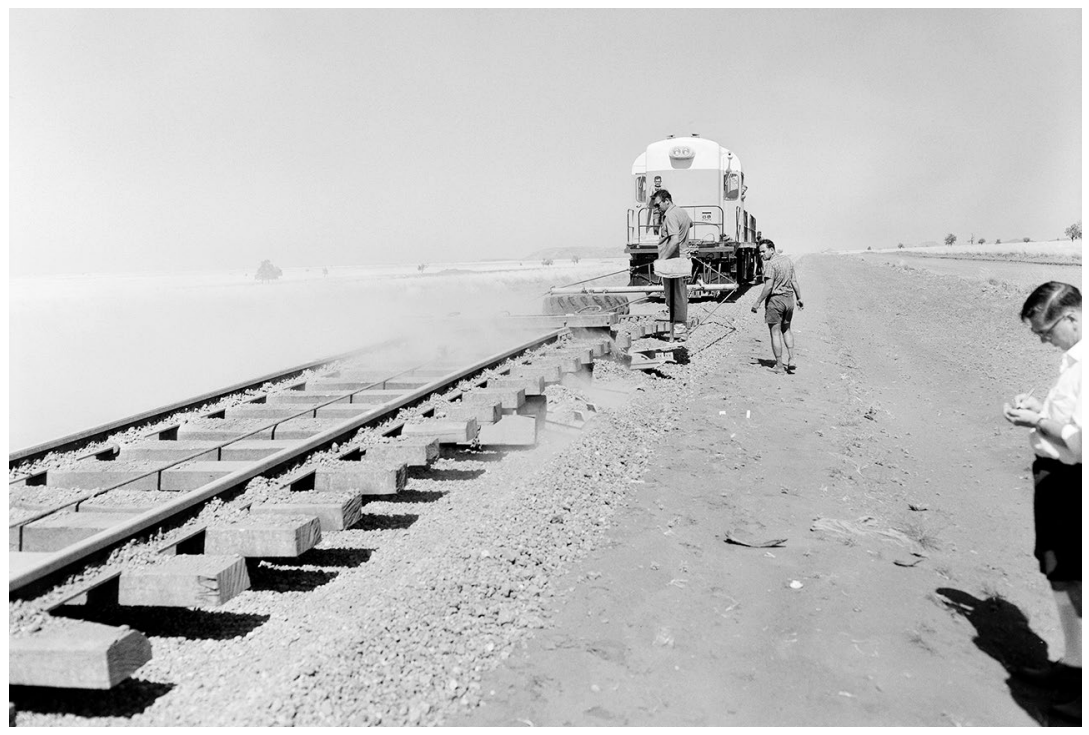

Figure 29. Construction of the railway line from Mount Goldsworthy mine site to Port Hedland, 1966.

Source: NAA, A1200, L54823.

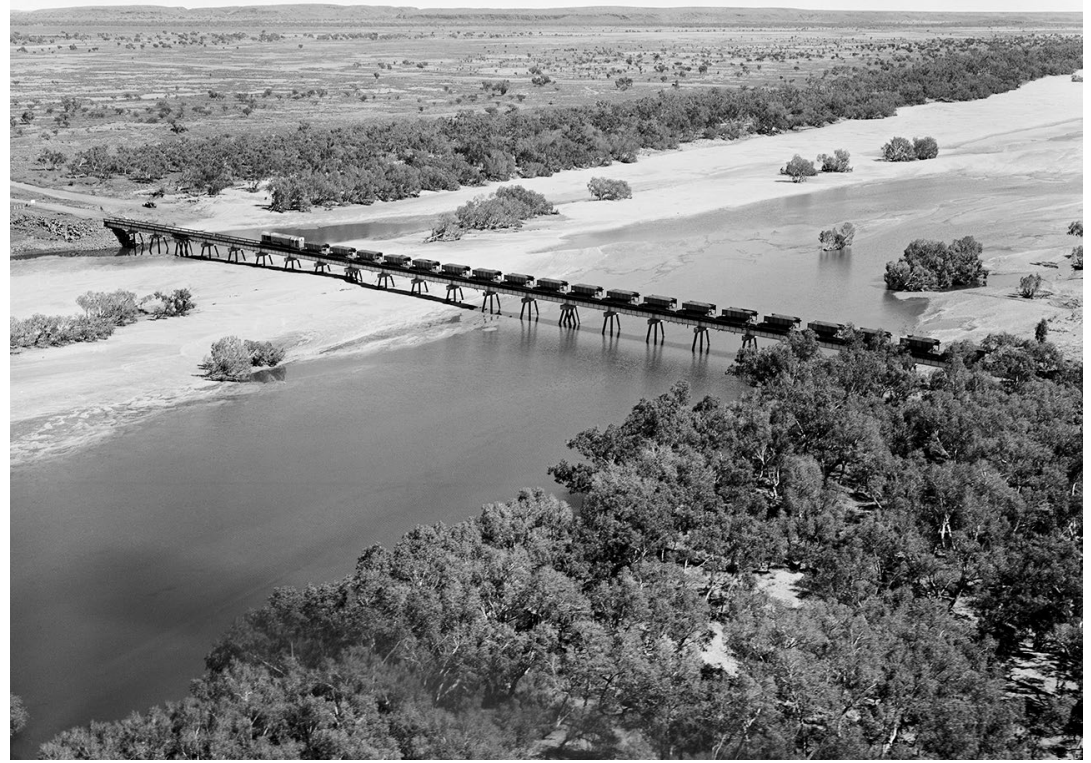

Figure 30. Iron ore train crossing De Grey River.

Source: NAA, A1200, L77644. 


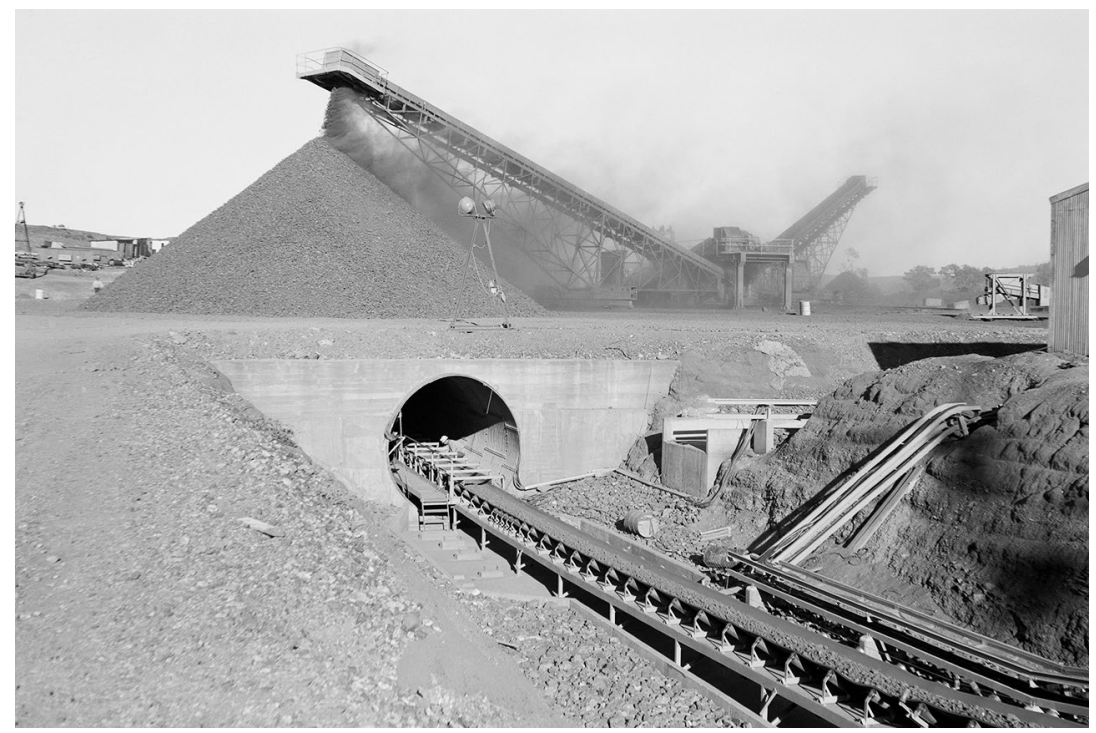

Figure 31. First iron ore shipment from Port Hedland in 1966, showing crushing facility at Finucane Island.

Source: NAA, A1200, L55248.

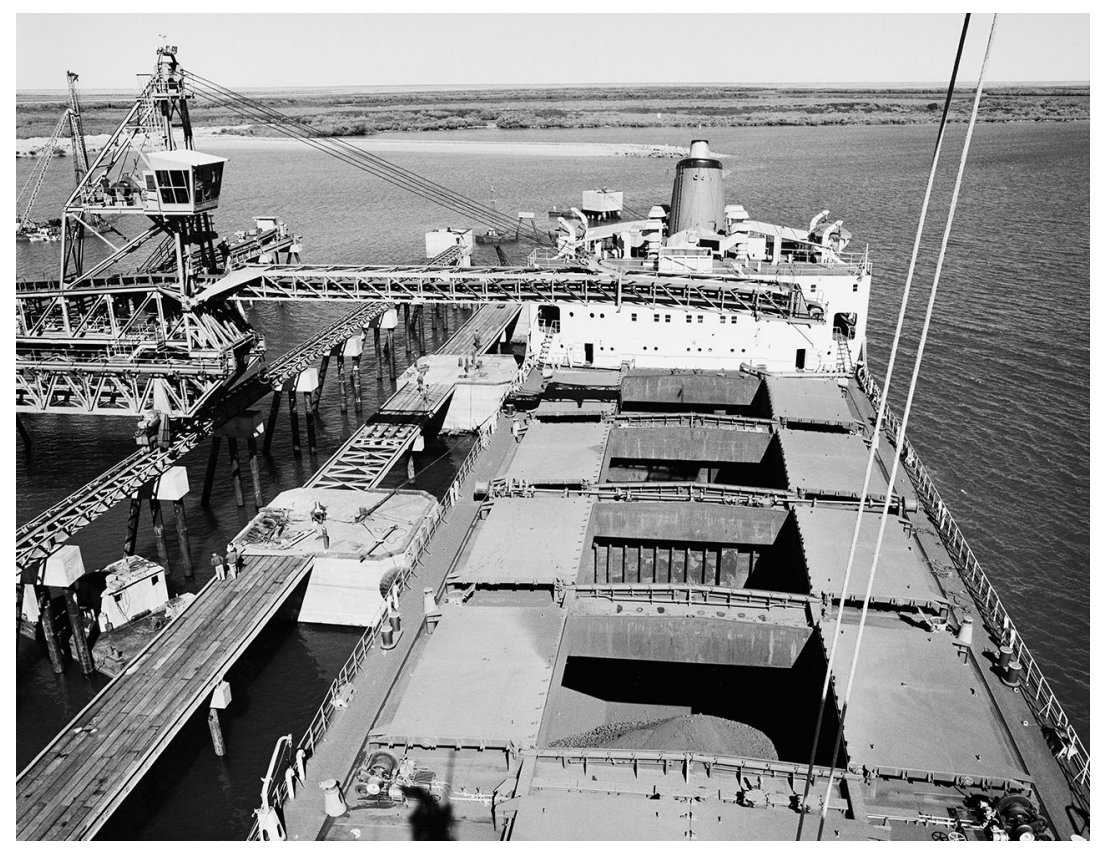

Figure 32. Ship loading, Finucane Island.

Source: NAA, A1200, L55411. 


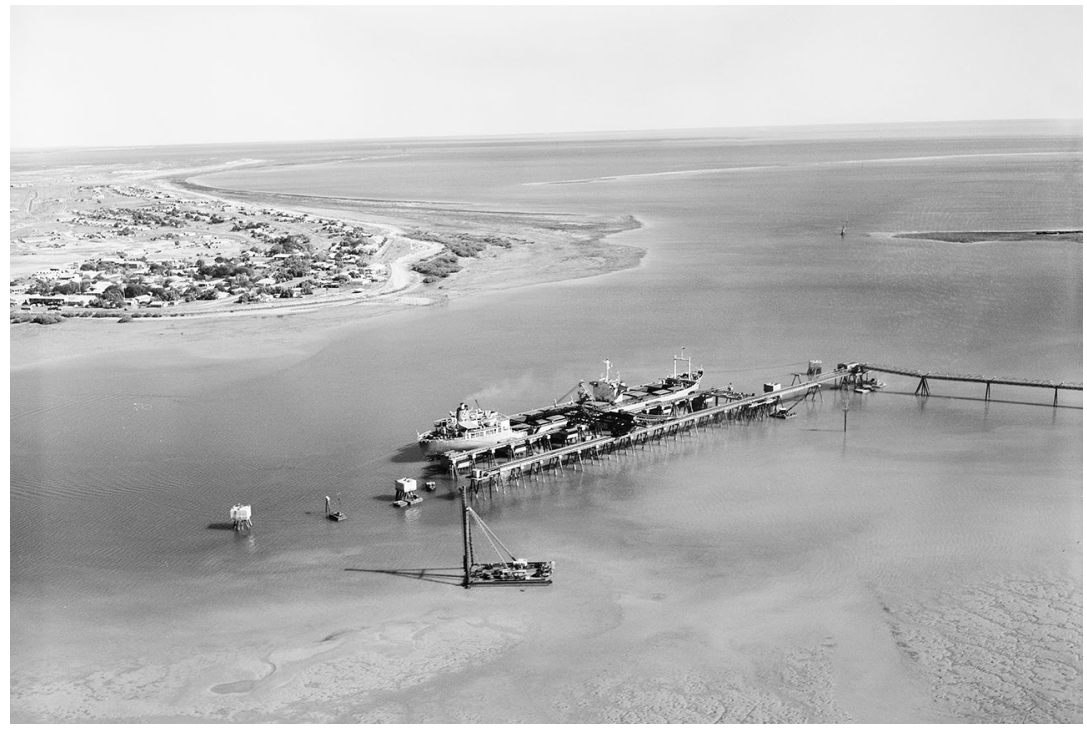

Figure 33. Harvey S Mudd at Finucane Island, 1966.

Source: NAA, A1200, L55410.

The initial contracts were estimated to generate US\$150 million for the joint venture. ${ }^{20}$ Financing for CGFA was by means of an arrangement whereby Gold Fields Mining \& Industrial advanced loan funds of A£14 million, unsecured and interest free, with A£9 million deemed to have been repaid by allotting Gold Fields Mining \& Industrial pre-paid shares in CGFA. ${ }^{21}$ In June 1966, the first shipment of Mount Goldsworthy iron ore of 20,000 tons was dispatched; an outcome achieved in a remarkably short period for such a major development and despite cyclonic weather washing away part of the railway in the weeks before the initial transportation of the iron ore. By 1967 CGFA had committed A $\$ 13$ million to the project, with an obligation for a further minimum payment of $\mathrm{A} \$ 9.5$ million. ${ }^{22}$

20 Goldsworthy Mining Pty Limited, UMA, Australian United Corporation, 1980.0088, Box 49.

21 Material Contract No. 10, UMA, 1974.0067.

22 This and other sections in the chapter make reference to both Australian pounds and Australian dollars. This reflects the conversion from imperial to decimal currency, which occurred on 14 February 1966. 


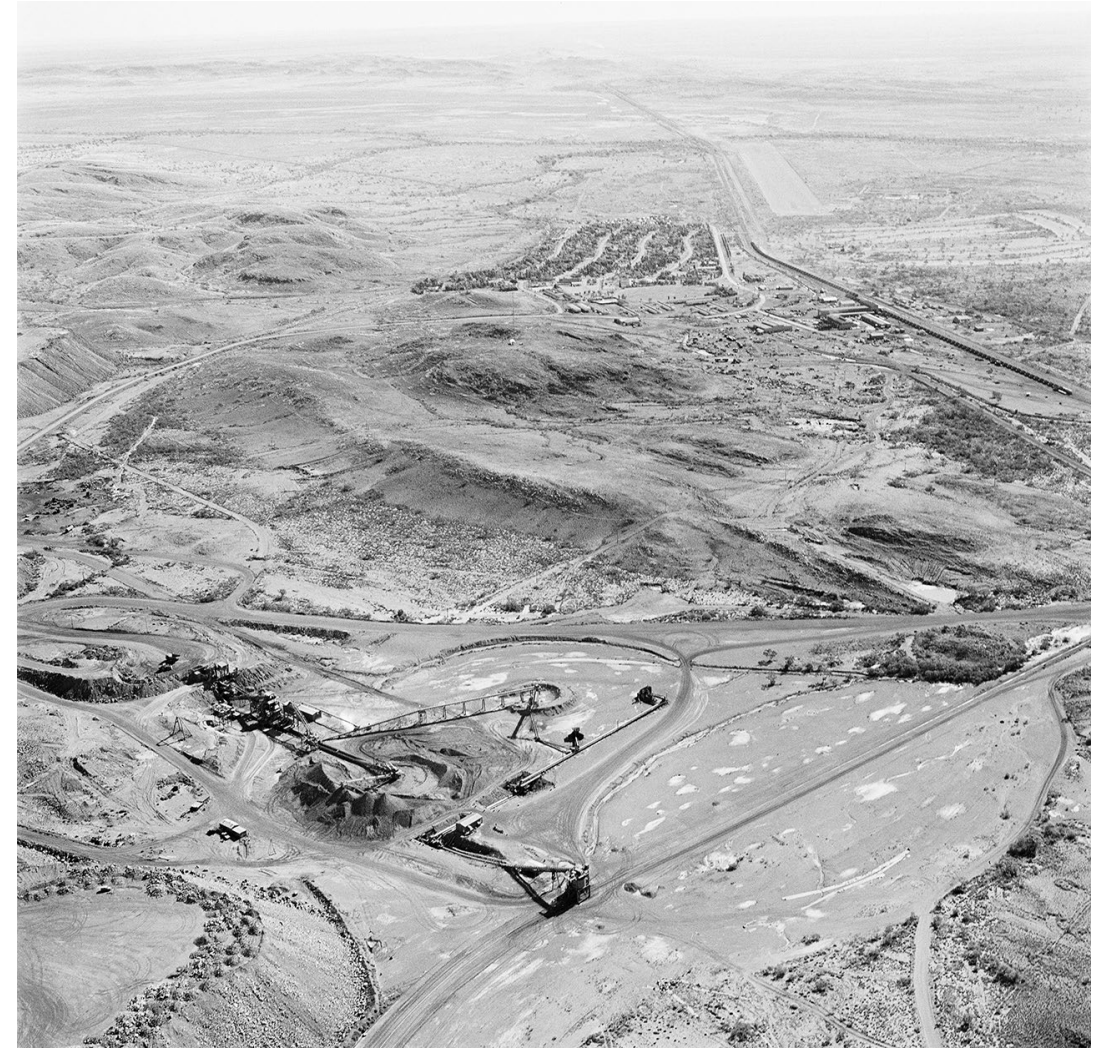

Figure 34. Aerial view of Mount Goldsworthy, Pilbara, Western Australia, 1974.

Source: NAA, A6180, 3/7/74/7.

The development of the first commercial iron ore production in the Pilbara by a British-American consortium was a massive undertaking and an impressive achievement for the newly established company in Australia, particularly given it was active on a number of fronts. Mount Goldsworthy represented the first direct operational venture in Australia for CGFA. Mortimer was instrumental in its development, facilitating the investment from London and spearheading the feasibility study work, as well as working to secure the enabling legislation for the project. He was viewed as the 'father' of Mount Goldsworthy for his efforts and, along with Paul Allen of Cyprus, was highly influential in the development and early management of this major Australian mining project. ${ }^{23}$ Mortimer

23 Cartwright, Gold Paved the Way, p. 290. 
became the first general manager of the project, seconded from London. Described by one contemporary as 'taciturn but effective', in Harvie-Watt's assessment he was a 'tower of strength to Gold Fields'. ${ }^{24}$ Mortimer went on to become chief executive officer and deputy chairman of Consolidated Gold Fields.

The Mount Goldsworthy joint venture was one of four groups that developed iron ore projects in the first half of the 1960s. The others were Hamersley Iron, a CRA and Kaiser Steel joint venture; Mt Newman Iron Ore Company, comprising BHP, CSR and AMAX; and Robe River, involving Cleveland Cliffs. In early 1965, apart from MGMA, two other major contracts for the supply of iron ore from the Pilbara to Japanese steel mills were signed, including 100 million tons from Mt Newman Iron Ore and 65.5 million tons from Hamersley Iron Ore. The Japanese steel mills used the period of contracting negotiations to apply pressure to their existing suppliers, out of India and Malaysia, as well as play the new Australian producers off against each other.

In this environment, consideration was given by MGMA to merging with another iron ore company, while Utah was willing to contemplate the Mount Goldsworthy joint venture facilitating Australian public participation in the project. The consideration by Utah was motivated in part by borrowing restrictions upon the non-Australian listed participants and a preference by some lenders to have equity as collateral. The level of investment for the Mount Goldsworthy development by CGFA, associated with other expenditure in Australia, meant that its British parent also envisaged the need to issue shares in CGFA to Australian investors as part of its funding considerations. While such considerations were not acted upon at the time of first production, they were factorsin an environment of increased resource nationalisation in the 1970s-to lead Mount Isa Mines to be invited to take an equity position in the Mount Goldsworthy project.

By December 1964, Consolidated Gold Fields had committed GBPE7 million to its investments in Australia and by 1966 this had increased to GBP£12 million. Despite five years of record profits by the British company, a pause in its earnings growth occurred in the 1966 financial year, caused by a loss from its American zinc interests, as well as

24 Harvie-Watt, Most of My Life, p. 252. 
restrictions on investments from the United Kingdom. In the light of its funding obligations, particularly for Mount Goldsworthy, a partial listing of the Australian subsidiary became a necessity. This occurred in 1966.

Australian iron ore production peaked in the early 1970s, affected by the circumstances of the Japanese steel industry where capacity was reduced in the face of falling international demand. In negotiations with the Japanese steel mills it proved extremely difficult to achieve price increases. The financial consequences of lower demand and flat prices were compounded by increasing costs, the problems in attracting workers and endemic industrial disputation. These factors led CGFA to re-evaluate its continued involvement in the iron ore industry. The need to commit substantial funds for the next mine development, Area C; other capital requirements of the group; and the weak financial performance of its wider portfolio in the early 1970s led to the decision to sell its interest in the company's single largest investment in Australia to that time. Both CGFA and Cyprus exited their involvement in the Mount Goldsworthy joint venture in 1976 .

\section{Manufacturing interests}

Diversification from minerals formed part of the investment decisionmaking of CGFA in the first half of 1960s. The company established a direct shareholding in two manufacturing companies and also participated in smaller direct investments related to industrial companies. Consolidated Gold Fields in London held a majority shareholding in Alumasc, a United Kingdom die-casting business that was a major producer of aluminium casting. An attraction of this business was its involvement in the manufacture of aluminium beer kegs. In December 1961, Alumasc made a takeover offer for the Australian company RH Lawrenson Holdings. The acquisition occurred and the company, renamed Lawrenson Alumasc Holdings, became a subsidiary of CGFA. The business, based at Lidcombe in New South Wales, undertook both metal and plastic die-casting. At a Consolidated Gold Fields management conference in Scotland in 1964, Brian Massy-Greene, in reviewing the investments of the new Australian entity, referred to the history of Alumasc since it had been acquired as not a 'very happy one', although the manufacture of beer 
kegs was expected to 'find an interesting place in Australian industry'. ${ }^{25}$ At the 1965 annual general meeting for Lawrenson Alumasc Holdings, two years after CGFA had invested in the business, and in the context of a reported loss, Massy-Greene observed: 'The die-casting industry is one which continues to be faced with fierce competition and low profit margins on its products'. ${ }^{26}$ In 1969, CGFA acquired Consolidated Gold Fields' shares in Alumasc Limited in the United Kingdom and from June of that year Lawrenson Alumasc Holdings was owned 56.5 per cent by CGFA. Lawrenson Alumasc Holdings was retained in the portfolio, with additional investments in acquiring associated business, until sold to Borg Warner (Australia) and James N Kirby in January 1978.

In April 1964, Massy-Greene reported to the Australian board of directors on negotiations being conducted in New Zealand for the acquisition of a 51 per cent interest in the manufacturing company Zip Holdings. Massy-Greene, with his background at the Metal Manufactures group, had a familiarity with the Zip Holdings business. It produced a range of domestic products, including water heaters, irons and electric jugs. Part of the attraction of this company was that, in New Zealand, number plates for vehicles were replaced each year associated with vehicle registration renewal. After a review by the London board, CGFA was given approval to proceed with the acquisition, for just over A£1 million. In July 1964 the company became a subsidiary of CGFA. The initial years saw an improvement in the profitability of the company. ${ }^{27}$ However, competitive pressures and increased costs adversely affected the financial performance of $\mathrm{Zip}$ Holdings and, as with Alumasc, the shareholding was sold, in 1976 at a profit on the sale of shares of $\mathrm{A} \$ 358,000$.

25 JB Massy-Greene, 'Gold Fields in Australia', in Consolidated Gold Fields Limited, 'Speeches Given at the Group Conference Held at Gleneagles Hotel, Scotland on 2-9 July, 1964', p. 156.

26 The loss was A£47,326 (Lawrenson Alumasc Holdings Ltd, 'Address by Chairman to the Shareholders of Lawrenson Alumasc Holdings Limited at the Fifteenth Ordinary General Meeting of the Company, 21st September 1965', UMA, Stock Exchange of Melbourne, 1968.0018, Box 733).

27 Profit after tax in 1964 was just over $A \$ 500,000$ and $A \$ 492,000$ in 1965 . Profit after tax in 1962 was $\mathrm{A} \$ 144,000$ and A $\$ 165,000$ in 1963 (Consolidated Gold Fields Australia Limited, 'Prospectus', 18 October 1966, UMA, 1974.0092, Box 857). 


\section{Bellambi Coal}

Sir Ian Potter, the Melbourne-based stockbroker and businessman, had an influence upon two CGFA investments in 1964: The Bellambi Coal Company and The Mount Lyell Mining and Railway Company. Bellambi Coal was incorporated as a listed company in 1923 following the liquidation of a previous company of the same name, established in 1888. The company conducted coking coal operations on the south coast of New South Wales with an operation at South Bulli Colliery, near Port Kembla.

The major coal-producing province on the south coast of New South Wales had over 10 coal exporters. Bellambi was the fourth-largest Australian colliery and the attraction to CGFA was that it offered 'enormous reserves' and was well placed to take advantage of the growing export market with Japan. ${ }^{28}$ The increase in Japanese steel manufacturing activity in the late 1950s and early 1960s led to an increased demand for Australian coal. Bellambi had entered the export trade for coal during 1962 and, as with other producers, took advantage of the burgeoning demand for coking coal by the Japanese steel industry. While CGFA had undertaken joint exploration with Utah in the Bowen Basin, Queenslandto become the major coal production province of Australia - it had not taken this association forward. An involvement, through Bellambi Coal, represented an attractive opportunity for CGFA to broaden its business presence in Australia.

Potter was chairman of Mcllwraith McEacharn, a company that provided stevedoring and shipping services to Bellambi Coal and had a shareholding in the company. Following discussions in London with Consolidated Gold Fields directors, Potter forwarded a letter to MassyGreene in May 1964 offering to sell stock units it held in Bellambi Coal to CGFA. The offer was conditional upon CGFA 'acquiring control but not full ownership' of the company. ${ }^{29}$ The purchase of stock units at a cost of A£238,952 occurred in 1964. CGFA had also acquired Bellambi shares through the stock market, representing 17.5 per cent of the issued

28 JB Massy-Greene, 'Gold Fields in Australia', in Consolidated Gold Fields Limited, 'Speeches Given at the Group Conference Held at Gleneagles Hotel, Scotland on 2-9 July, 1964', p. 154.

29 Letter from Sir Ian Potter, Chairman, McIlwraith McEacharn Limited to JB Massy-Greene, 8 May 1964; Consolidated Gold Fields (Australia) Pty Ltd, 'Minutes of Meeting of Directors (Australia) Pty Ltd', 15 April 1964, RGCA, Box 12264. 
capital of the company. This provided the basis for CGFA to make a formal offer to other Bellambi shareholders. The company's directors supported the offer, viewing it as a basis 'to greatly facilitate the provision of finance necessary for the immediate and long-term development' of the Bellambi operation, including expanding domestic coal sales and those to export markets, as well as extending coke production. ${ }^{30}$ Massy-Greene was appointed chairman and in 1964 CGFA owned 65.6 per cent of the company.

After CGFA acquired its holding, a production expansion program was committed to, entailing expenditure of A£1.9 million in 1965 for the installation of mechanised long-wall excavation equipment, extensions to the coal preparation plant and other infrastructure. In the same year, an arrangement was secured with Japanese steel mills and other customers for the supply of 1.25 million tons of coal for three years from March 1967. The adoption of new mining techniques, including the use of long-wall mining equipment, and access to new reserves, were seen as the means to increase production and greatly improve operating efficiencies at the mine. The initial years for CGFA were favourable, with the first annual general meeting of Bellambi Coal under CGFA ownership reporting a profit increase of $A £ 49,263$ to $A £ 120,442$ and a return on capital of 21.5 per cent. However, as with other investments, Bellambi Coal had a variable performance during CGFA's ownership, influenced by a range of factors including frequent labour stoppages and disruptions, the imposition of levies and financial charges, as well as impediments in dealing with the New South Wales Government in gaining approvals for access to new deposits. During the 1970s, issues with equipment reliability, the adverse effect on coal demand associated with the downturn in the Japanese steel industry, industrial disputes and a Commonwealth Government coal export levy created serious operational and financial issues for Bellambi Coal. CGFA decided, in the face of such factors, to sell its 64 per cent shareholding in $1980 .^{31}$

30 'Offer by Consolidated Gold Fields (Australia) Pty Ltd to Acquire Stock in the Issued Capital of The Bellambi Coal Company Limited 1964', UMA, Stock Exchange of Melbourne, 1968.0018, Box 33 .

31 The sale occurred to a Shell Company of Australia subsidiary, Austen \& Butta, and McIlwraith McEacharn. Proceeds were $\mathrm{A} \$ 19.1$ million, representing a capital profit of $\mathrm{A} \$ 16$ million on the investment (Consolidated Gold Fields Australia Ltd, 'Chairman's Address, Annual General Meeting 15th October, 1980’, UMA, Stock Exchange of Melbourne, 1987.0138, Box 70). 


\section{Copper-The Mount Lyell Mining and Railway Company}

What was considered a fundamental investment for the new mining group in Australian was the gaining of a controlling interest in the historic Mount Lyell copper mining, milling and smelting operation at Queenstown in the north-west of Tasmania in 1964. With this investment, CGFA also gained an indirect interest in the Renison tin operation near Zeehan, 40 kilometres away. As it transpired, Renison formed a key business interest for the group. Both remained major components of the CGFA and RGC portfolios until the second half of the 1990s.

Mount Lyell was initially worked for gold with copper mineralisation discovered in 1893, the year of the formation of Mount Lyell Mining and Railway Company. Mining first occurred at the Iron Blow ore body until the 1920s by both underground and open cut mining methods. By the 1930s, mining had shifted to lower-grade deposits at Mount Lyell, suitable for open cut mining, which continued through to 1972 when replaced by underground mining. Power was obtained from a hydroelectric power station at Lake Margaret. Smelting had been undertaken at Queenstown since 1896. The valleys of Queenstown were often blanketed in a yellow, acrid fog from the billowing smoke stacks of smelters used to treat the pyritic ore. The nearby hills were denuded, first for timber used in shafts and then by the effects of the sulphurous air and acid-forming rain. Smelting and refining operations ceased in 1969 under the control of CGFA. ${ }^{32}$ Subsequently, the Mount Lyell operation was confined to the milling and the sale of blister copper and later copper concentrates, sent by rail to Burnie.

In 1958, the chairman of Mount Lyell, Sir Walter Bassett, became concerned that the company may be under takeover threat from Rio Tinto. He wrote to the general manager, HM Murray, opening his confidential letter: 'This is an appeal for immediate and urgent action'. He continued:

32 Over this period 656,402 tons of blister copper was produced containing 650,618 tons of fine copper, 16,408,630 ounces of silver and 646,632 ounces of gold (Annual Report 1 August 1970, p. 9 in Mount Lyell Mining and Railway Company Limited, Operating Reports 1970, National Archives of Australia, Tasmania (NAAT), Series NS3924, Items 533-540). 
I am certain that we are going to be faced soon with an offer of 'collaboration' by Rio Tinto, whose only idea of collaboration is that of the tiger's complete swallowing. They are wealthy and ambitious and can be utterly unscrupulous. I suspect, too, that they are vindictive because we refused to accept their terms for joint exploration in the north-west and because they now think that we have beaten them to it at Renison. ${ }^{33}$

Bassett had been approached by the group chairman of Rio Tinto for a luncheon in London, a request that Ian Potter, a stockbroker to Rio Tinto, had urged Bassett to accept. Bassett was willing to accommodate a meeting, but saw no need to dine with Rio Tinto's chairman. At the meeting, he was offered financing from Rio Tinto to enable Mount Lyell to increase its production. Bassett respectfully listened, bemused as to why Mount Lyell should accept such an offer even if it accorded with its plans. Basset was later approached by the secretary of Rio Tinto to make arrangements for the Rio Tinto chairman and a number of senior technical personnel to visit the Mount Lyell operation. Again, Bassett felt it would be inappropriate to refuse such a request. However, his suspicions regarding Rio Tinto's motivations were all but confirmed when he enquired of Rio Tinto why such a 'top-brass party' was interested in travelling to Queenstown. Bassett recorded that Rio Tinto's managing director hesitated and then said: 'Well, all I can tell you is that we are not going all that way for the benefit of our health'. ${ }^{34}$ Believing a takeover may be imminent, Bassett advised Murray:

If this is Rio's plan, as it might quite well be, and it could happen almost overnight, our only chance ... is to persuade the market to appreciate our shares as quickly as possible in order to, if possible, make the take-over price prohibitive ... There is apparently nothing else we can do at this stage, and in time, such as splitting the company into two component parts, or writing up our assets and issuing bonus shares.

And now I come to the immediate task ... Will you please look into this for, say, a $50 \%$ increase and alternatively for a $100 \%$ increase in output, mainly, if not all, from the open cut. ${ }^{35}$

33 'Personal and Confidential to Hugh Murray, Penghana, Queenstown, 25 October 1958', NAAT, NS1711/1/770.

34 ibid.

35 ibid. 
Murray's response to Bassett was to propose developing an underground mining operation at Prince Lyell, rather than expanding the open cut. In his view, this would facilitate access to the extensive deeper reserves and be more profitable than expanding existing operations. ${ }^{36}$ Bassett's concerns with Mount Lyell's vulnerability to be taken over, in the context of Rio Tinto's apparent intentions, were confirmed when another company made an approach to acquire Mount Lyell. This set in train a series of events that ultimately enabled CGFA to acquire a majority shareholding in Mount Lyell. This outcome was facilitated by Boral, a company introduced to the Mount Lyell board of directors by Potter to protect it from an unwelcome takeover offer by Bolivian tin interests.

In 1961, Mount Lyell Mining and Railway Company was reconstructed into two companies. One was an investment company, Mount Lyell Investments, which had holdings in Metal Manufactures, Email, Imperial Chemical Industries of Australia and New Zealand, and Cuming Smith, as well as fertiliser interests through a number of companies. ${ }^{37}$ After the reconstruction, the other company, The Mount Lyell Mining and Railway Company, retained its existing mining assets and a shareholding in Renison which it had acquired in 1958, as well as a shareholding in Imperial Chemical Industries of Australia and New Zealand. ${ }^{38}$ Consolidated Gold Fields' valuation area in London had decided that Mount Lyell Investments was an appropriate entity for its Australian subsidiary to consider, both for diversification purposes and because of its cash position. In November 1962, CGFA contemplated a merger with Mount Lyell Investments in the form of a reverse takeover. ${ }^{39}$ In February 1963, CGFA representatives met the directors of Mount Lyell Investments in Melbourne. The proposal for a merger was 'not well received' and did not progress. ${ }^{40}$ While CGFA continued to buy shares in Mount Lyell Investments, by July 1963 Mount Lyell Investments had been acquired by another company.

36 Letter from HM Murray, general manager, to WE Bassett, chairman of directors, 30 October 1958, NAAT, NS 1711/1/770.

37 These companies were Commonwealth Fertilisers and Chemicals, Mount Lyell Fertilisers, Australian Fertilizers and Wallaroo-Mount Lyell Fertilisers.

38 The Mount Lyell Mining and Railway Company Limited, 'Circular to Shareholders: Reconstruction of the Company', 29 November 1961, UMA, Stock Exchange of Melbourne, 1968.0018, Box 190.

39 Cartwright, Gold Paved the Way, p. 296.

40 The Times, 14 December 1962 and 2 December 1964. 
CGFA recognised that Mount Lyell Mining and Railway Company, in its own right, provided an appropriate investment opportunity. A major attraction was the potential for expansion of production by accessing the deeper ore body below the existing open cut mine. Drilling at Mount Lyell had identified the potential of an estimated 40-50 million tons of ore at 1 per cent copper. In addition, Mount Lyell's shareholding in Renison was an attraction. A drilling program at Renison in the early 1960s provided encouragement of additional, deeper reserves in the existing Federal ore body, as well as a new ore body, the Bassett Lode in a footwall of Federal ore body. ${ }^{41}$ Consolidated Gold Fields in London was aware of the potential of the Renison mine and had established a direct shareholding in Renison. As such, the British and Australian arms of Gold Fields both understood that Mount Lyell and its interest in Renison offered a meaningful opportunity to establish a position in base metals.

In 1963, Mount Lyell Mining and Railway Company came under a foreign takeover threat. After previous overtures had been rebuffed, Patino Mining Corporation, a Quebec-based tin company, in association with British Tin Investment and Consolidated Tin Smelters, made a formal offer to acquire not less than 30 per cent and not more than 60 per cent of Mount Lyell's shares. The motivation was to acquire the 50 per cent shareholding that Mount Lyell held in Renison. The offer for Mount Lyell and, as such, its shareholding in Renison occurred in the same year that Bitumen and Oil Refineries (Australia) Limited (Boral) had acquired control of Mount Lyell Investments. ${ }^{42}$ Potter was influential in the arrangements involved in Boral gaining control of Mount Lyell, acting in his role as a 'de facto corporate planner for Boral, locating suitable acquisitions, carrying out negotiations with the target companies and delivering them to Boral at a good price. ${ }^{43}$

41 Mount Lyell, Confidential Paper, UMA, Stock Exchange of Melbourne, 1968.0018, Box 190; Raggatt, Mountains of Ore, pp. 379-380.

42 Boral was incorporated in March 1946 as Bitumen and Oil Refineries (Australia) Limited and changed its name to Boral Limited in November 1963.

43 Yule, Ian Potter: Financier and Philanthropist, p. 11. 
Bassett, as he had been in the case with Rio Tinto's unwelcome advances, had little interest in considering let alone accommodating the approach by Patino. According to Bassett, Patino's technical review of Mount Lyell's operations was both 'clandestine and most perfunctory'; in his view, Patino had 'no conception of the nature and magnitude of the difficulties still to face the mine'. ${ }^{44}$ For Bassett, 'such apparent carelessness' in its investment consideration of Mount Lyell could be explained only by Patino having no real concerns if the Mount Lyell operation failed, with its prime motivation to gain access to the Renison deposits. ${ }^{45}$ Discussions were held with the Commonwealth treasurer to persuade the government that the offer was not in the 'best interests of Australia', nor the company. ${ }^{46}$

The Patino takeover offer was rejected emphatically by the directors of Mount Lyell. In November 1963, Boral advised that it intended to make a counter offer to purchase not less than 30 per cent and not more than 50 per cent of the shares in Mount Lyell. The Boral offer, under the direction of its managing director, Elton Griffin, was readily accepted by the directors of Mount Lyell as in the interests of shareholders, as well as national interest. ${ }^{47}$ The acquisition occurred, with the 1964 Boral annual report observing that it was 'Boral's first venture into the Australian Metalliferous Mining industry' ${ }^{48}$

It was unlikely that Boral had a long-term intention of committing to a business investment in Mount Lyell and Renison. By April 1964, Boral had become aware of the level of capital expenditure required for both the operation and development of the Mount Lyell ore bodies. In a letter to Bassett on 8 April 1964, Griffin expressed concerns with the five-year capital expenditure plans of Mount Lyell, seeking an independent review of the longer-term mining outlook. ${ }^{49}$ In May, Griffin approached CGFA with the suggestion that it take over the direction of the technical management of Mount Lyell. Potter, given his recent engagement with

44 Mount Lyell, Confidential Paper, UMA, Stock Exchange of Melbourne, 1968.0018, Box 190. Underscoring in original.

45 ibid.

46 'Confidential. Discussion-Sir Walter Bassett with Treasurer, 31/10/63', p. 2, UMA, The Mount Lyell Mining and Railway Co, 1974.0067, Box Patino Offer.

47 The Mount Lyell Mining and Railway Company Limited, 'Circular to Shareholders: Take-Over Offers', 3 December 1963, p. 2, UMA, Stock Exchange of Melbourne, 1968.0018, Box 190.

48 Boral Limited, 18th Annual Report_Year ended June 30, 1964, p. 10, UMA, Stock Exchange of Melbourne, 1968.0018, Box 39.

49 Letter from Elton Griffin to Walter Bassett, 8 April 1964, UMA, The Mount Lyell Mining and Railway Co, 1974.0067, Box Boral Offer. 
CGFA and its London directors in relation to Bellambi Coal, identified the opportunity to offer some or all of the Boral shareholding to the newly established mining company seeking to broaden its Australian mining interests. Gold Fields in London had also decided to increase its stake in Mount Lyell 'either by bidding for a portion of the outside shareholdings and/or acquiring part of Boral's holding'. ${ }^{50}$

On 3 June 1964, CGFA was granted approval to send a technical team to Queenstown to undertake a detailed inspection and valuation exercise. The team comprised a range of Gold Fields technical personnel, drawn from the group's London, South African and American operations, headed by Mortimer. ${ }^{51}$ CGFA sought a firm option from Boral on the shares it was being offered, exercisable at the completion of the evaluation. Boral declined, instead giving CGFA the option to acquire 4 million shares at six shillings and sixpence eligible within 48 hours, or else negotiate both the quantity of shares and the price at the end of the valuation period, expected to be in a month. While the latter approach was favoured by CGFA, London directed that settlement occur on 4 June. This duly occurred.

Boral offered a further 198,886 shares at six shillings and sixpence, which gave CGFA a 29.74 per cent shareholding. By the end of the year, Boral was aware of the level of capital expenditure required for underground mining activities to access deeper reserves, as well as for the expansion of mining and milling operations at Renison. Griffin and Massy-Greene met on 7 December 1964. The meeting discussed the level of funds required for the exploration and development of underground reserves at Mount Lyell, estimated at $A £ 6.8$ million with a potential further $A £ 2$ million if a new refinery was constructed. Griffin wrote to Massy-Greene the following day: 'The information now at our disposal, indicating the large sums of money that will be required to fully develop Mt. Lyell has caused us to review our whole position with particular reference to our ability to

50 Segal, 'Notes on Redraft of Chapter XXV and XXVI of "History of Goldfields", 2 March 1966, p. 4, RGCA, Box 1091.

51 The Mount Lyell Mining \& Railway Coy Ltd, 'Memorandum for Sir Walter Bassett. From Secretary, Party to Visit Queenstown from Tuesday 16th June 1964', NAAT, NS1711/1/770. 
contribute our proportion of the contemplated amount' ${ }^{52}$ Boral offered CGFA its remaining shareholding of 4,840,112 shares at 11 shillings and sixpence. Sidney Segal recalled that:

Although the price was on the steep side, it was decided on 7th December to accept, making Mount Lyell a subsidiary of C.G.F. (A). with Lyell holding $49.9 \%$ of Renison, and Gold Fields [London] a small direct holding, Renison also became a subsidiary. ${ }^{53}$

The purchase price for these shares was $A £ 2,783,066$, the single largest share investment CGFA had made in Australia.

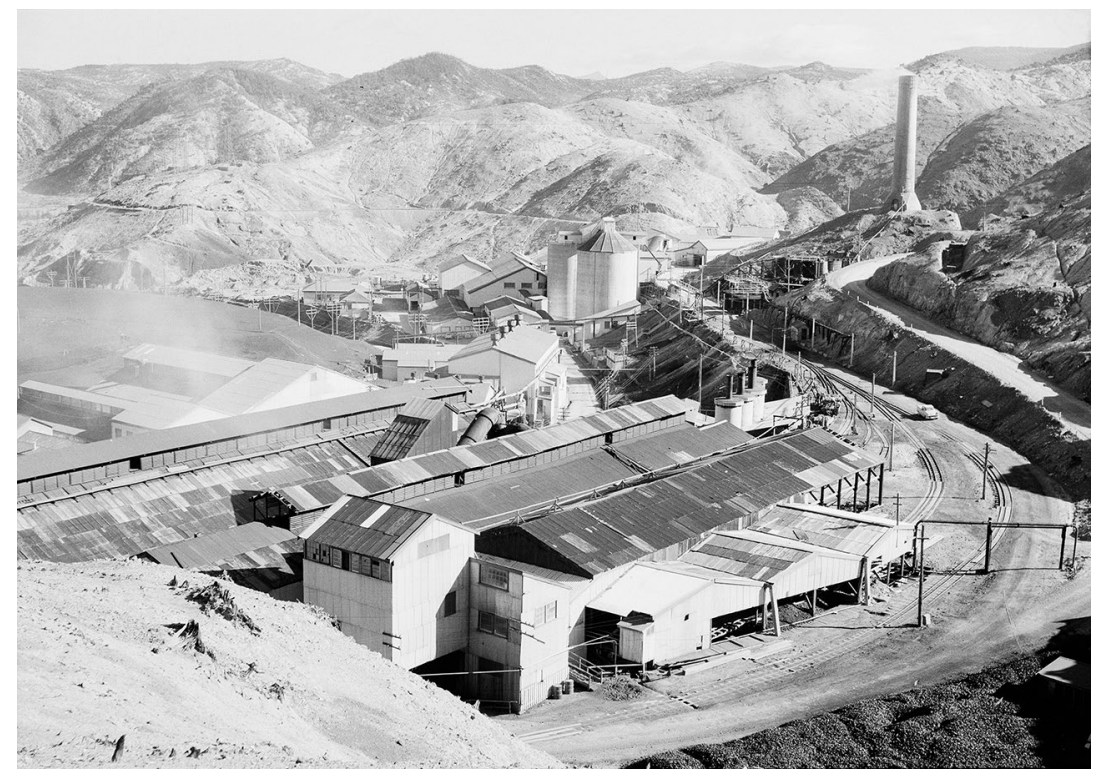

Figure 35. Mount Lyell Mining and Railway Company copper mining operation, Queenstown, 1963.

Source: NAA, A1200, L43495.

52 Material Contract No. 2, Correspondence between ER Griffin, general manager of Boral Limited and BH Massy-Greene, 8th December 1964, UMA, Mount Lyell Mining and Railway Co, 1974.0067, Box Consolidated Goldfields 1964-1966 Contracts.

53 Segal, 'Notes on Redraft of Chapter XXV and XXVI of "History of Goldfields"', 2 March 1966, p. 5, RGCA, Box 1091. 


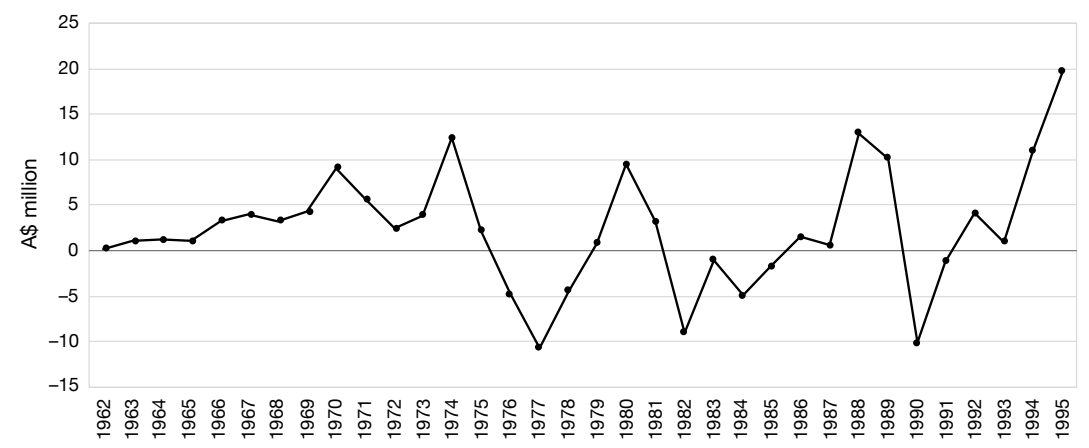

\section{Chart 2. Mount Lyell Mining and Railway Company pre-tax earnings, 1962-1995.}

Source: Consolidated Gold Fields Australia Limited, 'Prospectus', 18 October 1966; CGFA and RGC annual reports, 1967 to 1995 .

This chart shows the historical performance of Mount Lyell Mining and Railway Company within CGFA and subsequently as part of the Copper Division of RGC. Mount Lyell was the largest single investment in the portfolio in the 1960s. It offered the British group an interest in base metals, and an associated holding in the Renison tin operation. In the 1960s and early 1970s, Mount Lyell provided a strong earnings contribution. Subsequent performance was erratic with multiple loss-making years and severe challenges in terms of the continued operation of the mine, upon which the township of Queenstown was largely dependent. The operation closed at the end of 1994.

With the acquisition, CGFA acquired control of the Mount Lyell copper mine, as well as an interest in the 'jewel in the crown', Renison. In doing so, CGFA had established what was expected to be a long-life base-metal arm within its expanding Australian portfolio of mineral and manufacturing interests. However, CGFA's due diligence of the Mount Lyell operation had been limited at what was a crucial stage of its evolution. Large amounts of capital would be committed to transferring mining from the Prince Lyell open cut mine to underground mining. CGFA was largely content to retain existing Mount Lyell management for this exercise, with only a limited attempt to apply its own technical review to the approach being adopted for underground mining. This approach was modelled on that adopted at Mount Isa Mines, despite the different nature and grade characteristics of the two ore bodies. Operational challenges and consequential poor financial returns from CGFA's investment in Mount Lyell can be ascribed, in part, to the company not applying a greater level of management and technical oversight at the early stages of its involvement. The failure to do so reflected both a paucity of technical resources within CGFA during its initial years, as well as a tendency not to wish to intervene in the management affairs of its investments. 
In 1964, Massy-Greene and Mortimer became directors of Mount Lyell, with Brian W Andrew, the company's technical director, and Segal joining the board the following year. In October 1965, Bart Ryan, a mining engineer and later London director and managing director of CGFA, commenced at Renison as general manager.

With the acquisition of Mount Lyell, CGFA had gained a shareholding in a historic mining operation upon which the township of Queenstown and local region in the north-west of Tasmania depended for the major part of their employment, housing and other services. In 1969, more than 1,600 workers were employed by Mount Lyell. Turnover of the workforce was high. In the prior year, 618 men out of 1,555 had left the operation, reflecting both high employment levels in the wider economy, as well as the challenges of attracting and retaining married employees due to the shortage of suitable accommodation in Queenstown. ${ }^{54}$ The close relationship between the mining operation, the local population and the regional economy would have implications in future years as to the manner in which CGFA and RGC viewed the retention of their investment during periods of challenging market, operational and financial conditions.

The initial years of Mount Lyell as a subsidiary of CGFA were favourable. In 1966, a net profit of $\mathrm{A} \$ 2.3$ million was recorded, compared with A $\$ 840,000$ in 1964 , aided by a higher copper price. In 1967 , the profit increased to A $\$ 2.7$ million, the second of two years of record profits. As encouraging were exploration results in the Mount Lyell-Tharsis area and Prince Lyell ore bodies, which were testing the downward extension to depths of 2,500 feet below the open cut operation, which had extended to a depth of 1,250 feet. Drilling results indicated that additional copper-bearing ore of up to 45 million tons, containing 1 per cent copper, was obtainable. ${ }^{55}$ The prize was major.

The board of Mount Lyell approved the Prince Lyell feasibility study in July 1968. This led to the excavation of an ore shaft for the development of ore bodies below the West Lyell open cut, principally Prince Lyell, as well as the development of other ore bodies including Crown Three, Cape Horn and Twelve West. Associated works included underground crushing

541968 Annual Report, p. 4, in Mount Lyell Mining and Railway Company Limited, Operating Reports 1968, NAAT, Series NS3924, Items 533-540.

55 The Mount Lyell Mining \& Railway Company Limited, 'Directors' Report and Accounts and Chairman's Statement', 1964 and also 1965, 1966 and 1967, UMA, Stock Exchange of Melbourne, 1968.0018, Box 190 . 
facilities and new underground locomotives and rolling stock for ore haulage. Additional accommodation for the workforce was also planned. The smelter was closed and concentrate shipped to the main Japanese customer, with pyrite production to be used in a new acid plant to be developed in association with EZ Industries at Burnie. ${ }^{56}$

\section{Renison-the jewel in the crown}

Alluvial tin had been discovered in the Renison Bell area of Tasmania in 1890 and the first concentrating mill built in 1907. The recovery from tin-bearing gossans was exhausted by 1922. Renison Associated Tin Mines was formed with production recommencing in 1936 utilising flotation technology to recover tin sulphides. In 1958, Mount Lyell acquired a substantial interest in the company and in 1960 Renison Limited was registered to acquire the shares in Renison Associated Tin Mines. ${ }^{57}$

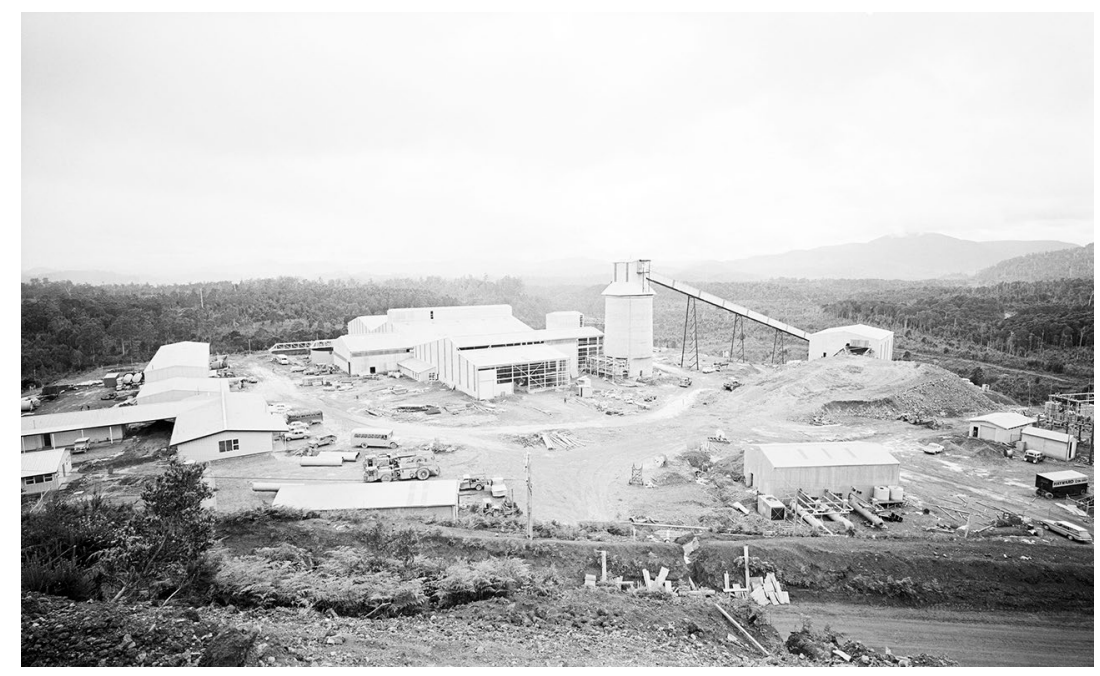

Figure 36. Renison tin mining operation near Zeehan, west coast of Tasmania.

Source: NAA, A1200, 16173841.

56 Annual Report, 1st August 1968, p. 13, in Mount Lyell Mining and Railway Company Limited, Operating Reports 1968, NAAT, Series NS3924, Items 533-540.

57 Renison Limited, Annual Report, 1978, p. 3 and Annual Report, 1974, p. 7. 


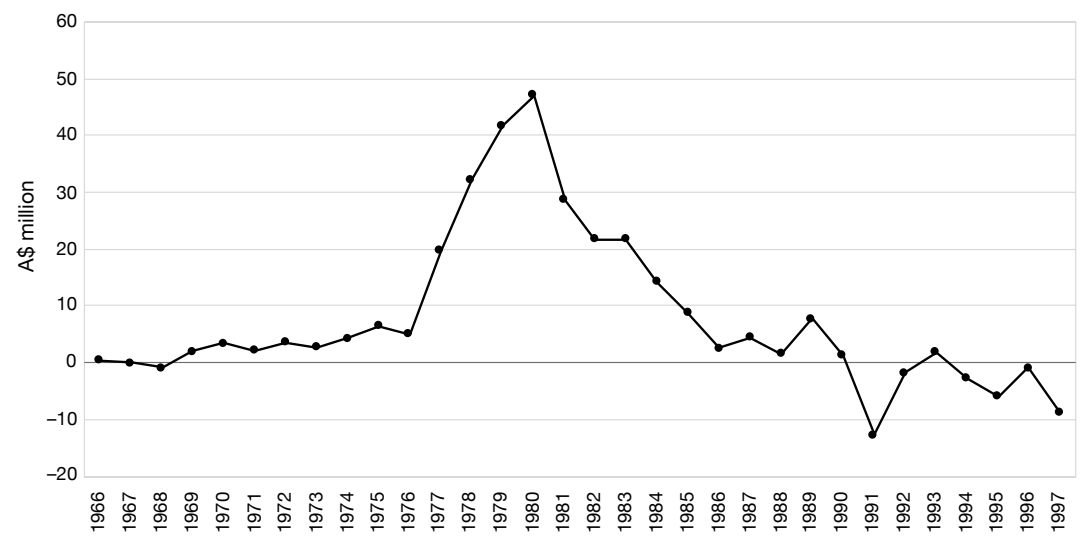

Chart 3. Renison pre-tax earnings, 1966-1997.

Source: Consolidated Gold Fields Australia Limited, 'Prospectus', 18 October 1966; CGFA and RGC annual reports, 1967 to 1997.

This chart shows the performance of Renison within the CGFA and RGC portfolios. Renison was a key investment for the British mining group, with an interest acquired through its holding in Mount Lyell Mining and Railway Company, before majority ownership was obtained. The steady returns in the late 1960s and early 1970s were followed by a marked improvement in financial performance in the late 1970s and Renison's spectacular contribution through the first half of the 1980s. The subsequent decline through the second half of the 1980s and 1990s led to a decision to sell the operation, which occurred in 1998.

With CGFA's acquisition of the majority stake in Mount Lyell in 1965, the company acquired an indirect interest in Renison. CGFA was involved in plans for the development of the mineral potential of Renison. The Renison board decided in 1965 to raise A£4 million for a major expansion program involving underground mining at the Federal ore body, as well as a new underground mine for the recently delineated Bassett ore body. The plans entailed diesel-powered underground mining and a new treatment plant capable of initial production of 350,000 tonnes of ore per year. Consolidated Gold Fields advanced loan funds of A£1 million in exchange for the ability to apply for up to 400,000 Renison shares within a three-year period. ${ }^{58}$ CGFA would exercise this option. Renison became a major financial contributor to CGFA over the next two decades and so pivotal within the portfolio that consideration was given in the 1970 s to the 'Renison scheme', a plan entailing the

58 Renison Limited, 'Circular to Shareholders: Major Expansion Scheme', 9 April 1965 and Material Contract No. 3, UMA, Mount Lyell Mining and Railway Co, 1974.0067, Box Consolidated Goldfields 1964-1966 Contracts. 
divestment of all assets in the portfolio, with the exception of a majority position in Renison. While this was not to eventuate, Renison was a key part of the portfolio in the late 1970s and first half of the 1980s.

With its wide-ranging Australian investments, CGFA had established an impressive presence as a diversified minerals company, with a major position in iron ore, mineral sands, copper and tin, a listed mining investment company and fledgling manufacturing interests. It continued to expand in the second half of the 1960s, using the model of majority controlled, direct investments, with the introduction of direct Australian shareholding in 1966. The London parent retained majority share ownership, a presence on the board of directors and considerable influence upon decision-making for the deployment of funds. The commencement of the group's investments in Australia in 1960 provided great promise that Consolidated Gold Fields, through its local subsidiary, would stand among the major mining companies in Australia. 
This text is taken from Consolidated Gold Fields in Australia: The Rise and Decline of a British Mining House, 1926-1998, by Robert Porter, published 2020 by ANU Press, The Australian National University,

Canberra, Australia.

doi.org/10.22459/CGFA.2020.08 